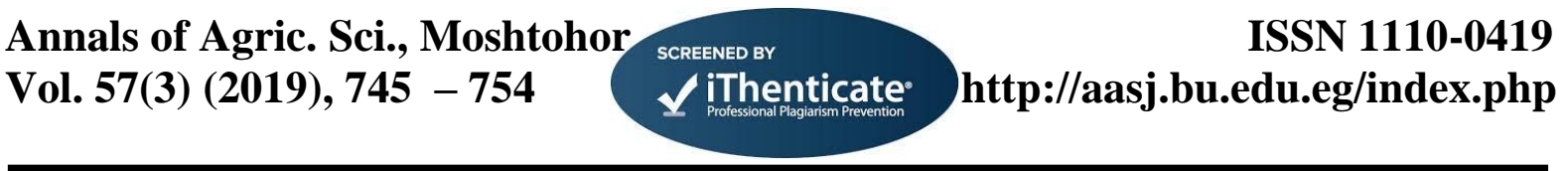

\title{
Influence of Some Host Plants and Temperature on Biological Aspects of the Citrus Brown Mite, Eutetranychus orientalis (Klein) (Acari: Actinedida: Tetranychidae)
}

\author{
ASHRAF S. ELHALAWANY \\ Fruit Trees Mites Department, Plant Protection Research Institute, Agricultural Research Center, Dokki, Giza, Egypt. \\ Corresponding author: dr_ashraf_said@yahoo.com
}

\begin{abstract}
The citrus brown mite (CBM), Eutetranychus orientalis (Klein, 1936) is a key pest of citrus, date palm, filed crops and ornamentals. Development time, reproduction and life table parameters of E. orientalis were studied on leaves of six host plants: castor bean, date palm, Indian laburnum, mulberry, plum and sweet potato under laboratory conditions of 25 and $30 \pm 2{ }^{\circ} \mathrm{C} ; 65 \pm 5 \%$ R.H. and photoperiod of 16L: 8D. Results indicated that the highest life cycle was $19.95 \& 9.38$ and $19.31 \& 9.8$ days for male and female on date palm at 25 and $30^{\circ} \mathrm{C}$, while, the lowest value of this period was obtained on castor bean were $16.45 \& 16.75$ days for male and female at $25^{\circ} \mathrm{C}$, and $6.31 \& 8.43$ days for male and female at $30^{\circ} \mathrm{C}$ on Indian laburnum, respectively. Mean longevity of female $E$. orientalis ranged from 13.53 to 15.13 days at $25^{\circ} \mathrm{C}$, and from 9.9 to 16.9 days at $30^{\circ} \mathrm{C}$. The highest mean total fecundity was 19.45 and $14.1 \mathrm{eggs} /$ female on Indian laburnum and castor bean at 25 and $30^{\circ} \mathrm{C}$, respectively. The sex ratio \% (female/ total) ranged from 65 to $76 \%$. The highest intrinsic rate of increase $\left(\mathrm{r}_{\mathrm{m}}\right)$ was 0.143 on Indian laburnum at $25^{\circ} \mathrm{C}$ and 0.138 (individuals/ female/ day) on castor bean at $30^{\circ} \mathrm{C}$. The individuals had the ability to double with the shortest time at $30^{\circ} \mathrm{C}$ (4.81 days) on Indian laburnum and the longest time at $25^{\circ} \mathrm{C}(12.38$ days) on date palm. The mean generation time (T) and generation doubling time (DT) values decreased with temperature increase. This mite favored high temperature; castor bean and Indian laburnum were more favorable hosts than others.
\end{abstract}

Key words: Biology, life table, Temperature, Eutetranychus orientalis, host plants.

\section{Introduction}

Eutetranychus orientalis (Klein) commonly known as oriental red mite, citrus mite and citrus brown mite was described by Klein (1936) under the name Anychus ricini. E. orientalis is an important pest of citrus and is a persistent pest in Upper Egypt. It also infests a wide variety of other crops including apple, peach, grape, guava, papaya, date palm, grapevines, quince, cotton, eggplant, cucurbits and a variety of ornamentals. The mites colonize the upper side of leaves where they feed, and their damage develops as yellow-grey stippled spots which cause leaf wilting and drop. Heavy infestations can cause fruit drop and the death of upper branches, and nextyears blossoming may be severely affected. All active stages of the mite cause damage (Rasmy, 1977; Jeppson et al. 1975; Zaher, 1984, Elhalawany, 2001, El-Halawany et al. 2001, Abdelgayed et al. 2017).

Comparing the life table parameters is the most suitable method to study the effect of host plant on mite suitability. Several studies on the biology of spider mites on their host plants have been published thus far (Al-Gboory, 1991, Assari, 2001, Dingxu et al. 2006, Imani and Shishehbor, 2009 and Sangeetha et al. 2013)

The objective of this study was to study the effect of different host plants and temperature on the biology and life table parameters of E. orientalis, under laboratory conditions. The obtained data of these experiments were used to understand the mechanism of population build-up of mite, $E$. orientalis on different hosts.

\section{Material and methods}

\section{Mite collection:}

Experiments were conducted at Qaha Agriculture Research Station (ARC), Qalyubia governorate, Egypt. Six test plants were used for studied the biological aspects of citrus brown mite, E. orientalis on castor bean (Ricinus communis L.), date palm (Phoenix dactylifera L.), Indian laburnum (Cassia fistula L.), mulberry (Morus alba L.), plum (Prunus domestica L.), sweet potato (Ipomoea batatas L.).

Biological study of citrus brown mite $E$. orientalis:

Laboratory colonies of E. orientalis were collected from infested castor bean plants Qaha Agriculture Research Station (ARC), Qalyubia governorate, Egypt in June 2017. Seeds of castor bean plants were planted in pots containing soil and leaf compost. After suitable growth, plants were infected with $E$. orientalis. The stock colony was maintained in small greenhouse $5 \times 5 \mathrm{~m}^{2}$. After several generations, mites from the stock colony were used for the tests. The identity of Identification of $E$. orientalis was conducted using the key given by (Krantz and walter, 2009, Zaher, 1984). The 
specimens were deposited in the (PPRI- ARC) Plant Protection Research Institute, Giza, Egypt.

\section{Rearing $E$. orientalis on leaf of different host} plants:

The study of the mite life cycle was carried out on six previous mentioned plants at 25 and $30 \pm 2^{\circ} \mathrm{C}$, $65 \pm 5 \%$ R.H, and photoperiod of 16L: 8D. Six holes (2 $\mathrm{cm}$ diameter) were opened in a Petri dish $(15 \mathrm{~cm}$ diameter) plastic cover. Small other holes in the cover were made to provide water with the help of a medical syringe. Six discs of six different host plants (leaves) $(2.5 \mathrm{~cm}$.) were put on cotton piece in Petridish. All leaves were placed ventral-side up. Discs were replaced when needed to maintain the level of nutrition and vitality, A piece of cotton dampened with water put between the cover plate and around the edges of the disk and painted with vaseline to prevent mites escape. About 50 pairs of newly molted females and males from the stock culture were introduced each to a leaf disc. After mating on the leaves in the laboratory, females were allowed to lay eggs for 12-h periods. One egg was transferred for each disc using a brush 00 and up to 30 replicates were made for each treatment. Petri dishes were examined twice daily to record the different developmental stages. This method was proposed by (Elhalawany, 2013).

To study the parthenogenesis the first 10 quiescent female deutonymphs that molted to females and laid their first batch of eggs. Observation these eggs to complete life cycle of the individual mites were traced for mated females and virgin females.

During developmental period, mortalities of different stages and sex ratio of progeny were specified. Oviposition by result at females was recorded daily for each female. Life table parameters were estimated according to (Birch 1948) using the Life48, BASIC Computer programmed (Abou-Setta et al. 1986). Parameters were determined by the following formula:

$\max \Sigma_{0}$ Lx m x / exp. $r_{m} x=1$

Where $" m_{x}$ " is the number of daughters produced per female during the interval " $\mathrm{x}$ ". " $\mathrm{L}_{\mathrm{x}}$ " is the fraction of lively females at age " $x$ ". The values of " $r_{m}$ " is a natural logarithm of the intrinsic rate of increase and indicates the number of times of population multiplication in a of time unit. The net reproductive rate $\left(R_{0}\right)$ is the mean for female multi-placation in one generation (. "T" is the mean length of generation period, expressed in days, while DT means time of population to double, and "GRR" means Gross reproduction rate calculated. These definitions were presented by Birch (1948). $\mathrm{R}_{0}=\Sigma\left(1 x \times \mathrm{m}_{x}\right) ; \mathrm{T}=\Sigma(\mathrm{x}$ $\left.\times 1_{\mathrm{x}} \times \mathrm{m}_{x}\right) / \Sigma\left(1_{\mathrm{x}} \times \mathrm{m}_{x}\right) ; \mathrm{r}_{\mathrm{m}}=\mathrm{Ln}\left(\mathrm{R}_{0}\right) / \mathrm{T} ; \mathrm{DT}=\mathrm{Ln}(2) /$ $\mathrm{r}_{\mathrm{m}}, \lambda=\exp \left(\mathrm{r}_{\mathrm{m}}\right)$ and $\mathrm{GRR}=\Sigma \mathrm{mx}$.

\section{Statistic analysis:}

Data were statistically analyzed using one-way and two-way analysis of variance ANOVA and mean separation was conducted using Duncan's multiple range test $(\mathrm{P} \leq 0.05)$. These analyses were conducted using SAS statistical software (SAS Institute, 2003).

\section{Results and Discussion}

\section{Developmental time and longevity}

The life cycle of citrus brown mite, E. orientalis is completed and passed throughfour developmental stages with quiescence stages at the end of larval and nymphal stages. The development times of immature stages of (CBM) are given in Tables $(1,2$, 3 and 4). Development time decreased as temperature increased for both females and males. Generally development times were shorter for males than females.

Significant differences for each stage were found between the mean developmental times at the different temperatures and host plants. Obtained results presented in (Tables 1\&2). Differences between the incubation periods of females were small. Significant differences were found between the six rearing plant hosts. The shortest female incubation period, larva, protonymphal, deutonymphal stages, total immature stages and life cycle were $6.68,3.6,3.23,10.08$ and 16.75 days at $25^{\circ} \mathrm{C}$ on castor bean; while the longest were 7.29 , $4.33,3.95,3.75,12.03$ and 19.31 days on date palm; respectively. The longest developmental time of immature stages of male were $11.7 \& 11.75$ days on date palm and mulberry at $25^{\circ} \mathrm{C}$; while the shortest were $9.75,10$ and 10.15 days at $25^{\circ} \mathrm{C}$ on castor bean, Indian laburnum and sweet potato; respectively. There were non-significant differences between incubation period, larva and deutonymphal stages of males reared on six host plants Table (2).

Female longevity of E. orientalis ranged from 13.53 to 15.13 days at $25^{\circ} \mathrm{C}$; while life span ranged from 31.35 to 33.35 days. Whereas, male longevity and life span ranged from $11.65 \& 29.1$ to $13 \& 31.6$ days at $25^{\circ} \mathrm{C}$, respectively (Tables $1 \& 2$ ).

Applying the same tests as shown in (Table $3 \& 4$ ) indicated that differences between the six plant hosts were small at $30^{\circ} \mathrm{C}$. All female and male immature stages developed faster on Indian laburnum, but slowed on date palm and mulberry. The female longevity was longest on castor bean (16.9 days), followed by Indian laburnum (14.5 days), and were shortest on date palm, mulberry and plum (10.6, 9.9 and 10 days), respectively. A similar trend was observed for both female and males. The female life span ranged from 19.03 to 25.6 days, while the male life span ranged from 17.94 to 25.38 days.

Adult female generation, longevity and fecundity

The emergence of females after moulting immediately followed copulation and active feeding prior to the beginning of oviposition. Males either wandered actively, searching for females for mating. Mated females of E. orientalis ovipositor eggs which 
developed into both males and females. On the other hand, the eggs deposited by virgin females forever developed into males only this phenomenon is called Arrhenotoky female these observations are in agreement with Sangeetha et al. 2013.

The aforementioned results in (Table 5) clarified that generation time (from egg to egg) of the (CBM) fed on castor bean, Indian laburnum and sweet potato were the shortest and significantly shorter than of those fed on date palm and mulberry at 25 and $30^{\circ} \mathrm{C}$.

Significant difference was observed for the duration of pre-oviposition, oviposition and postoviposition periods. The shorter periods were recorded on castor bean, Indian laburnum and the longest periods were found on date palm and mulberry at 25 and $30^{\circ} \mathrm{C}$ (Table 5).

E. orientalis female deposits eggs singly in a linear fashion on the upper leaf surface, mostly along the midrib near the lateral veins. Significant differences were found in fecundity the highest being in those fed on, Indian laburnum 19.45eggs/o, followed by those fed on castor bean 18.2eggs/ + , while the lowest fecundity was $8.15 \mathrm{eggs} / \%$ fed on date palm at $25^{\circ} \mathrm{C}$. Similar results was recorded at $30^{\circ} \mathrm{C}$ the highest fecundity found on castor bean followed by Indian laburnum and the lowest number obtained when mite fed on date palm. In addition, the daily rate of female has significant affected by host plant the highest rate when female fed on castor bean, Indian laburnum were 1.66 and $1.78 \mathrm{eggs} / \mathrm{O} / \mathrm{day}$ at $25^{\circ} \mathrm{C}$, while the highest values at $30^{\circ} \mathrm{C}$ were 1.63 and 1.56 eggs/O/ day when mite fed on plum and mulberry, respectively.

The obtained results are in harmony with that detected by Siddig and Elbadry, 1971 who study the biology of E. sudanicus Elbadry on citrus, results indicated that the incubation period averaged 5.7 and 4.3; larval period 3.7 and 2.9; protonymphal period 2.4 and 1.7; deutonymphal female period 2.7 and 2.2; and deutonymphal male period 2.4 and 2.0 days, in winter and summer, respectively. The pre-oviposition, oviposition, and post-oviposition periods averaged 2.4 and 1.0, 12.2 and 10.4, and 3.0 and 2.4 days, in winter and summer, respectively. Atwa et al. 1987 indicated that at $30^{\circ} \mathrm{C}$, egg incubation period and immature stage development period and adult longevity were $3.57,10.0$ and 7.36 days, respectively. The egg-toadult developmental time of the female was 12.43 days at $30^{\circ} \mathrm{C}$. The longevity of the female ranges from 16.57 days at $20^{\circ} \mathrm{C}$ to 7.50 days at $30^{\circ} \mathrm{C}$. The fecundity ranges from 14.56 to 16.33 eggs per female, and the sex ratio is $75-80 \%$ female. Al-Gboory, 1991 found that developmental time of E. orientalis was 11.85 days on mandarin at $28{ }^{\circ} \mathrm{C}$. The mean longevity of females was 8.75 days, whereas the female produced only 5 eggs during oviposition period. Assari, 2001 reported that E. orientalis life span at $28^{\circ} \mathrm{C}$ and $20 \%$ relative humidity was 5 days for males and 8 days for females. Badii et al. 2003 found that the durations of E. banksi for pre-oviposition, oviposition and post- oviposition periods, as well as adult longevity, decreased with rising temperature in the range of 25$30^{\circ} \mathrm{C}$. With the exception of the pre-oviposition period, temperature of $20^{\circ} \mathrm{C}$ had an opposite effect on the durations of the remaining adult phases.

The mean total and mean daily fecundities generally but irregularly declined with ascending temperatures. The influence of host species of deciduous fruit trees, like apple, peach, plum, cherry and apricot, on the development and reproduction of the hawthorn spider mite Tetranychus viennensis Zacher in the laboratory. They indicated that plum might be the best suitable plant for the spider mite among the plants tested due to shorter developmental period and higher intrinsic rate of increase, whereas cherry and apricot were least suitable due to their long developmental duration and low intrinsic rates of increase (Dingxu $\boldsymbol{e t}$ al. 2006). Imani and Shishehbor, 2009 studied the life history of E. orientalis on Lebbek tree at four constant temperatures $\left(20^{\circ}, 25^{\circ}, 30^{\circ}\right.$ and $\left.35^{\circ} \mathrm{C}\right)$. Developmental time of female from egg to adult ranged from $22-32$ days at $20^{\circ} \mathrm{C}$ to 12.43 days at $30^{\circ} \mathrm{C}$. Mean longevity of female ranged from 16.57 days at $20^{\circ} \mathrm{C}$ to 7.50 days at $30^{\circ} \mathrm{C}$. Mean total fecundity ranged from 14.56 to 16.33 eggs/ female. These results are lower than those recorded by AbdelWahed and Elhalawany, 2012 they denoted that the effect of temperature and host plant on biological aspects of Tetranychus urticae Koch. The longest developmental stages reached 30.6 and 30.1 days for female and male at $15^{\circ} \mathrm{C}$ when the T. urticae was fed on Lacont pear variety, while when reared on Hood pear variety it was 34 and 32.1 days at the same temperature. The highest total mean fecundity rate was recorded at $30^{\circ} \mathrm{C}$ (156.8 and 143.6 eggs/female). In the next year, Elhalawany and Abdel-Wahed, 2013 indicated that the reproduction, survival, and life table parameters of T. urticae on Kostata and Hachiya Persimmon cultivars leaves were studied under laboratory conditions of $15,20,25$ and $30^{\circ} \mathrm{C}, 70 \%$ RH. The shortest period of incubation, immature stages and female longevity were 3.27, 8.92 and 12.98 days, while these periods on males were 3.35, 7.8 and 11.8 days at $30^{\circ} \mathrm{C}$ on Kostata persimmon variety, respectively.

\section{Factorial analysis of obtained biological aspects of $\boldsymbol{E}$. orientalis}

This type of analysis considers the effect of each studied factor (i.e. temperature, and host pant) regardless of other factors. 


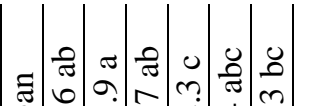 \\ की

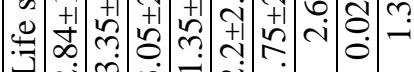 - लं ले ले लिं

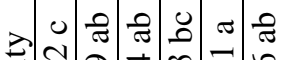

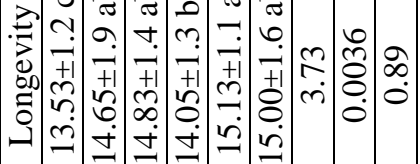

๑)

包

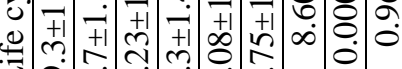

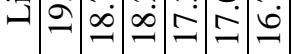

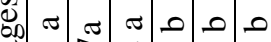

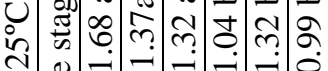

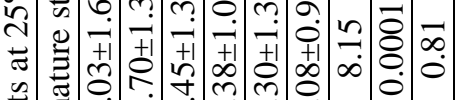

䓌

苛

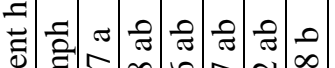

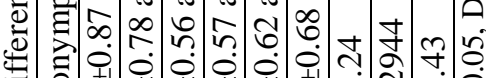

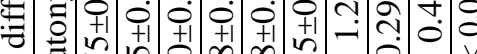

ธี चัँ

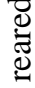

2.

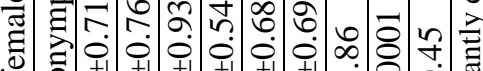

(2)

चे

ปิ)

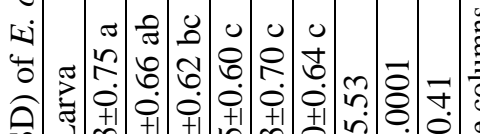

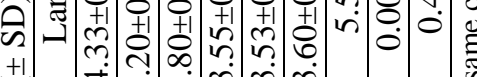

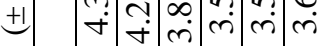

ఫ্টة

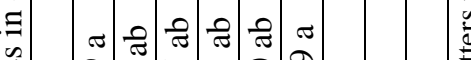

छ

ت

焉

के

究

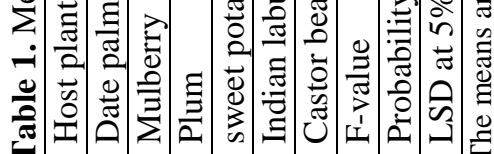



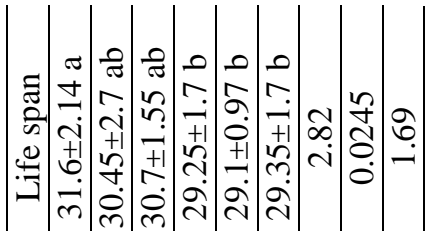

$\Rightarrow$ ㄱำ

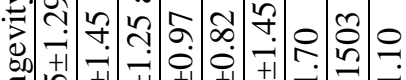

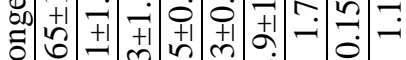

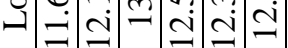

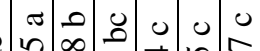

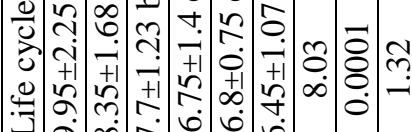

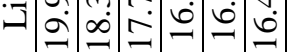

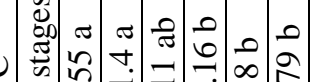

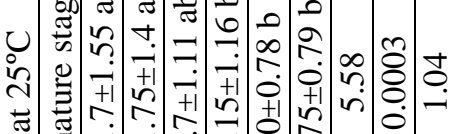

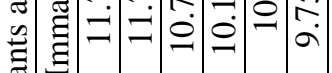

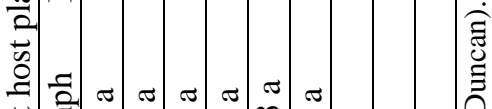

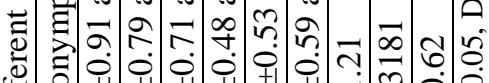

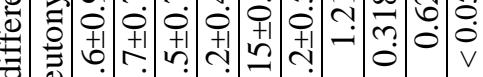

च̆

면

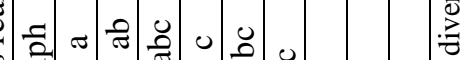

音

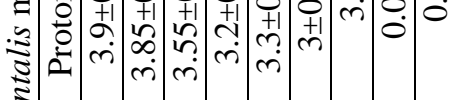

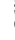

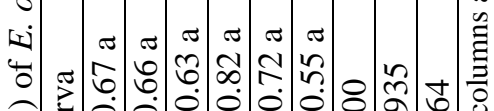

ชิ

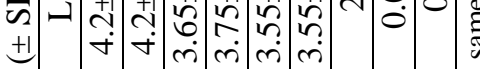

窇

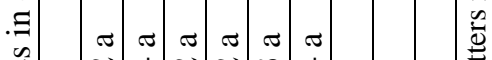

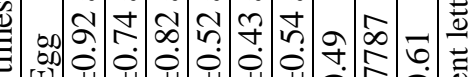

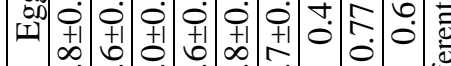
家

흠

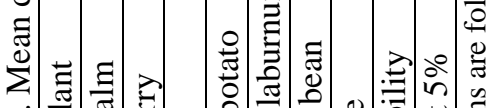
ن

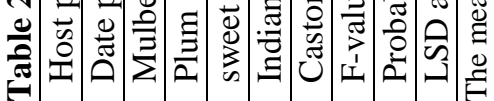

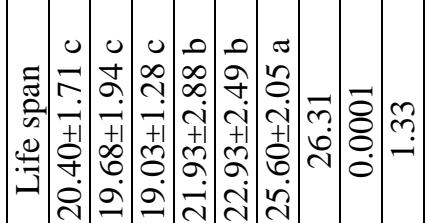

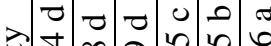

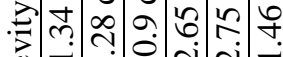

列卉

б웅 웅

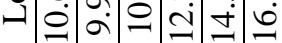

๑ $\pi$ 의

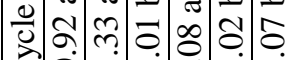

它完势

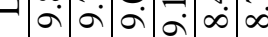

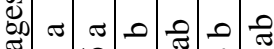

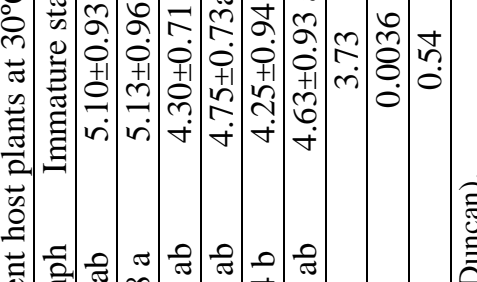

矛

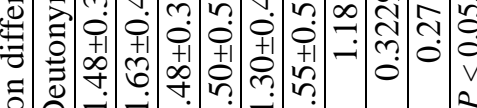

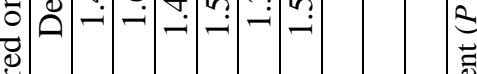

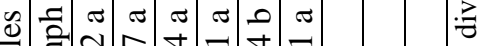

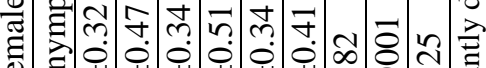

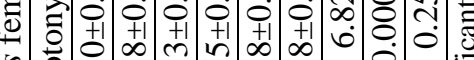

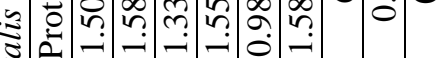

पั

प्य $\approx$ สิ 0 สิ

Ч

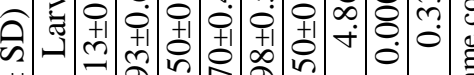

\pm \#

胥

झ $\approx \pi \approx \frac{\pi}{\pi} 0$

๘)

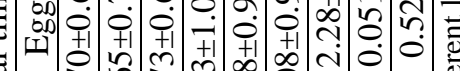

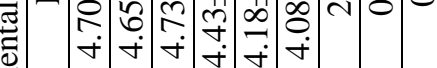

产

$\frac{0}{0}$

ठำ

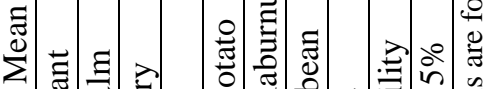
m.

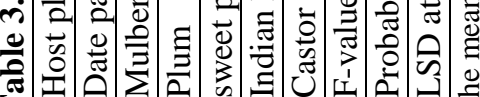




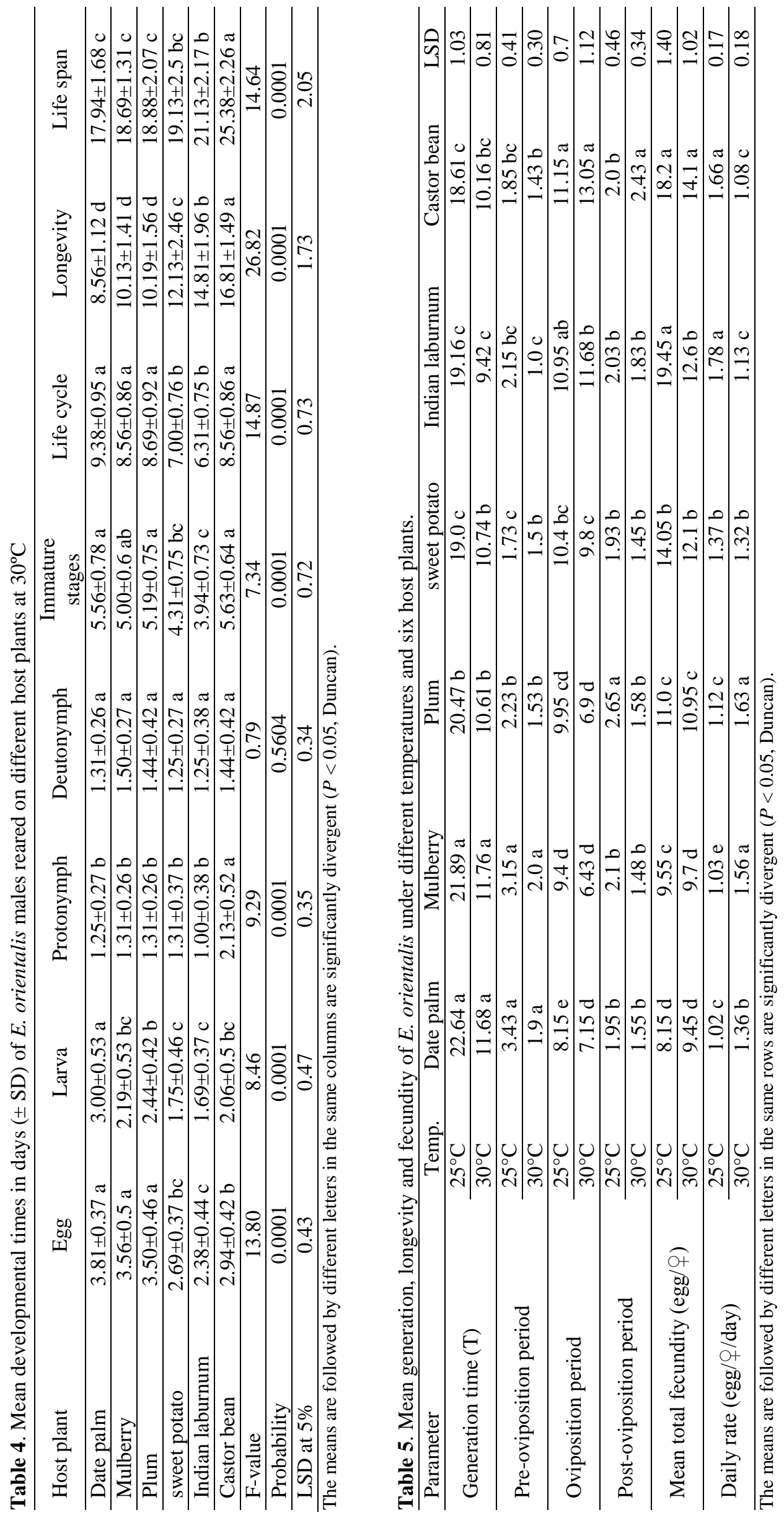




\section{Effect of host plant:}

The results illustrated in (Table 6) proved that the mean duration of all developmental stages were longer on date palm and mulberry followed by plum and sweet potato and the shortest duration were recorded on Indian laburnum and castor bean plants. Significant differences were found between developmental periods of (CDM) exposed to different source of food. The shortest life cycle and generation time were on Indian laburnum and castor bean plants; while the longest of these periods were on date palm and mulberry. Significant differences were also found between adult female longevity, oviposition period and life span. The castor bean plants were more favored to the mite followed by Indian laburnum more than date palm and mulberry. Moreover, significant differences occurred between the six hosts fecundity was the highest on Indian laburnum and castor bean plants and the lowest on date palm and mulberry. These results are agreement with finding by (Singh et al. 2000) found that development of this mite has been recorded much faster on castor and can actively grow on temperate fruits like apple and pear during March to June.

\section{Effect of temperature:}

The optimum temperature for development was $30^{\circ} \mathrm{C}$, being faster than $25^{\circ} \mathrm{C}$. Significantly differences occurred between all stages at the two levels of temperatures.

The highest fecundity at $25^{\circ} \mathrm{C}$ was $13.4 \mathrm{eggs} / \mathrm{female}$, while the lowest was at $25^{\circ} \mathrm{C}$ was 11.48 eggs/female (Table 6).

These findings are more or less similar to that detected by (Rasmy 1977) who reported that $E$. orientalis was reared on leaves of sour orange, orange and mandarine. Variation was noted in the fecundity was distinctly affected: The sour orange leaves promoted a high number of eggs, whereas rearing on mandarine leaves led to the poorest fecundity. In addition, Eutetranychus banksi (McGregor) developed from egg to adult in 13.1, 11.6, 11.7 and 9.6 days compared to $12.0,10.1,10.8$ and 8.5 days for males at $25,28,30$ and $32^{\circ} \mathrm{C}$ on . Developmental times were significantly different between the two sexes at each temperature (Childers et al. 1991). Also, Elhalawany, 2013 indicated that immature stages of date palm dust mite Oligonychus afrasiaticus (Mc.G.) was fastest on karmry stage (10.60 days) followed by yellow khelal (12.35 days) then inner fronds (12.71 days). The shortest generation time was $9.5,11.32$ and 16.04 days at $35^{\circ} \mathrm{C}$, while the longest was $22.74,26.74$ and 26.68 days at $25^{\circ} \mathrm{C} \& 70 \%$ R.H. on karmry, yellow khelal stage and inner frond; respectively.

\section{Life table parameters}

The life table parameters of E. orientalis at two constant temperatures and six host plants are shown in (Table 7). Mean generation time (Tc) declined with increasing temperature. The shortest doubling generation time (DT) the time required to double the number of the individual mites, occurred on Indian laburnum and castor bean were 4.81 and 5.02 days at $30^{\circ} \mathrm{C}$ and the longest period on date palm was 12.38 days at $25^{\circ} \mathrm{C}$.

Gross reproduction rate (GRR) recorded the highest value at $25^{\circ} \mathrm{C}$ on Indian laburnum was 33.7 eggs/ individual and the lowest value 6.42eggs/ individual on date palm. While these values ranged from 8.6 to 12.5 eggs/ individuals at $30^{\circ} \mathrm{C}$.

The net reproductive rate $\left(\mathrm{R}_{\mathrm{o}}\right)$ increased from 3.68 times/ individual/generation on date palm to 12.25 times/ individual/generation at $25^{\circ} \mathrm{C}$; whereas at $30^{\circ} \mathrm{C}\left(\mathrm{R}_{\mathrm{o}}\right)$ increased from 4.29 to 7.18 times/ individual/generation at the same hosts.

The maximum intrinsic rate of natural increase $\left(\mathrm{r}_{\mathrm{m}}\right)$ was recorded at $25^{\circ} \mathrm{C}$ on Indian laburnum (0.143individuals/ $/$ / day), and on castor bean at $30^{\circ} \mathrm{C}$ was $(0.138$ individuals/ $/$ day $)$. Whereas, the lowest values were $(0.056$ and 0.077 individuals/ P/day) on date palm and mulberry at 25 and $30^{\circ} \mathrm{C}$, respectively. The finite rate of increase $(\lambda)$ ranged from 1.05 offspring/ individual/day at $20^{\circ} \mathrm{C}$ on date palm to 1.15 offspring/ individual/day at $30^{\circ} \mathrm{C}$ on Indian laburnum. The population of this mite is reduced by half ( $50 \%$ mortality) from 27 to 29 days at $25^{\circ} \mathrm{C}$ and from 16 to 22 days at $30^{\circ} \mathrm{C}$. The sex ratio ranged from 0.65 to 0.76 female/ total not affected by temperature and host plant.

Age specific survivorship $\left(1_{\mathrm{x}}\right)$ and fecundity $\left(\mathrm{m}_{\mathrm{x}}\right)$ curves for E. orientalis are shown in Fig. (1) The daily age-specific survival rate was highest at $25^{\circ} \mathrm{C}$ and decreased as the temperature increased on six host plants. The maximum number of eggs produced on castor bean was at $25^{\circ} \mathrm{C}$ (day 22: $1.76 \mathrm{egg} / \mathrm{q} /$ day), the lowest value was obtained at $25^{\circ} \mathrm{C}$ (day 22: 0.81 egg/O/day) on date palm. The highest survival rate of females was $0.9 \%$ on castor bean at $25^{\circ} \mathrm{C}$, while lowest value was $0.65 \%$ on date palm and plum plants at $30^{\circ} \mathrm{C}$.

These results are in accordance with that of (Childers et al. 1991) who suggested that the intrinsic rate of increase $\left(\mathrm{r}_{\mathrm{m}}\right)$ of $E$. banksi was 0.066 , $0.123,0.179,0.210,0.224$ and 0.190 at $15,20,25,28$, 30 and $32^{\circ} \mathrm{C}$. Sex ratio was strongly biased toward females $(<80 \%)$ between 20 and $30^{\circ} \mathrm{C}$ and declined to $68 \%$ at $15^{\circ} \mathrm{C}$ and $61 \%$ at $32^{\circ} \mathrm{C}$. The maximum net reproductive rate $\left(\mathrm{R}_{\mathrm{o}}\right)$ was 31.26 at $28^{\circ} \mathrm{C}$ followed by 26.06 at $30^{\circ} \mathrm{C}$ and 25.29 at $25^{\circ} \mathrm{C}$. It has appears to have a higher intrinsic rate of increase between 28 $30^{\circ} \mathrm{C}$. Elhalawany, 2001 found that, the high fecundity of female (128.05 eggs/ + ) was recorded at $30^{\circ} \mathrm{C}$. In addition, the highest intrinsic rate of increase $\left(\mathrm{r}_{\mathrm{m}}\right)(0.29)$ was obtained at $30^{\circ} \mathrm{C}$ when Tetranychus urticae fed on Black michen fig variety, and lowest fecundity 32.68 eggs/ $/$ and the lowest $\left(\mathrm{r}_{\mathrm{m}}\right)(0.040)$ was obtained at $15^{\circ} \mathrm{C}$ on Gizi fig variety. 
Table 6. Factorial analysis of obtained biological aspects of E. orientalis as affected by temperature and host plant

\begin{tabular}{|c|c|c|c|c|c|c|c|c|c|c|}
\hline \multirow[b]{2}{*}{ Factor level } & \multicolumn{5}{|c|}{ Host plant } & \multirow[b]{2}{*}{$\begin{array}{c}\text { Castor } \\
\text { bean }\end{array}$} & \multirow[b]{2}{*}{ LSD. } & \multicolumn{2}{|c|}{ Temperature } & \multirow[b]{2}{*}{ LSD. } \\
\hline & $\begin{array}{l}\text { Date } \\
\text { palm }\end{array}$ & Mulberry & Plum & $\begin{array}{l}\text { sweet } \\
\text { potato }\end{array}$ & $\begin{array}{c}\text { Indian } \\
\text { laburnum }\end{array}$ & & & $25^{\circ} \mathrm{C}$ & $30^{\circ} \mathrm{C}$ & \\
\hline Egg & $5.99 \mathrm{a}$ & $5.83 \mathrm{ab}$ & $\begin{array}{l}5.75 \\
a b c\end{array}$ & $5.68 \mathrm{abc}$ & $5.48 \mathrm{bc}$ & $5.38 \mathrm{c}$ & 0.35 & $6.91 \mathrm{a}$ & $4.46 \mathrm{~b}$ & 0.20 \\
\hline larval & $3.23 \mathrm{a}$ & $3.06 \mathrm{a}$ & $2.65 \mathrm{~b}$ & $2.63 \mathrm{~b}$ & $2.75 \mathrm{~b}$ & $2.55 \mathrm{~b}$ & 0.26 & $3.83 \mathrm{a}$ & $1.79 \mathrm{~b}$ & 0.15 \\
\hline Protonymph & $2.73 \mathrm{a}$ & $2.71 \mathrm{a}$ & $2.74 \mathrm{a}$ & $2.45 \mathrm{ab}$ & $2.14 \mathrm{c}$ & $2.40 \mathrm{bc}$ & 0.27 & $3.64 \mathrm{a}$ & $1.42 \mathrm{~b}$ & 0.16 \\
\hline Deutonymph & $2.61 \mathrm{a}$ & $2.64 \mathrm{a}$ & $2.49 \mathrm{a}$ & $2.49 \mathrm{a}$ & $2.39 \mathrm{a}$ & $2.40 \mathrm{a}$ & 0.25 & $3.52 \mathrm{a}$ & $1.49 \mathrm{~b}$ & 0.14 \\
\hline $\begin{array}{l}\text { Immature } \\
\text { stages }\end{array}$ & $8.56 \mathrm{a}$ & $8.41 \mathrm{a}$ & $7.88 \mathrm{~b}$ & $7.56 \mathrm{bc}$ & $7.28 \mathrm{c}$ & $7.35 \mathrm{bc}$ & 0.50 & $10.99 \mathrm{a}$ & $4.69 \mathrm{~b}$ & 0.29 \\
\hline Life cycle & $14.56 \mathrm{a}$ & $14.24 \mathrm{a}$ & $13.63 \mathrm{~b}$ & $13.24 \mathrm{bc}$ & $12.75 \mathrm{c}$ & $12.73 \mathrm{c}$ & 0.59 & $17.89 \mathrm{a}$ & $9.15 \mathrm{~b}$ & 0.34 \\
\hline Generation & $17.22 \mathrm{a}$ & $16.81 \mathrm{a}$ & $15.50 \mathrm{~b}$ & $14.85 \mathrm{bc}$ & $14.33 \mathrm{c}$ & $14.36 \mathrm{c}$ & 0.67 & $20.30 \mathrm{a}$ & $10.73 \mathrm{~b}$ & 0.39 \\
\hline $\begin{array}{l}\text { Pre- } \\
\text { oviposition }\end{array}$ & $2.66 \mathrm{a}$ & $2.58 \mathrm{a}$ & $1.88 \mathrm{~b}$ & $1.61 \mathrm{bc}$ & $1.58 \mathrm{c}$ & $1.64 \mathrm{bc}$ & 0.27 & $2.42 \mathrm{a}$ & $1.56 \mathrm{~b}$ & 0.15 \\
\hline Oviposition & $7.65 \mathrm{~d}$ & $7.91 \mathrm{~d}$ & $8.43 \mathrm{~d}$ & $10.10 \mathrm{c}$ & $11.31 \mathrm{~b}$ & $12.10 \mathrm{a}$ & 0.76 & $10.0 \mathrm{a}$ & $9.17 \mathrm{~b}$ & 0.44 \\
\hline $\begin{array}{l}\text { Post- } \\
\text { oviposition }\end{array}$ & $1.75 \mathrm{~b}$ & $1.79 \mathrm{~b}$ & $2.11 \mathrm{a}$ & $1.69 \mathrm{~b}$ & $1.93 \mathrm{ab}$ & $2.21 \mathrm{a}$ & 0.30 & $2.11 \mathrm{a}$ & $1.72 \mathrm{~b}$ & 0.17 \\
\hline Longevity & $12.06 \mathrm{~d}$ & $12.28 \mathrm{~d}$ & $12.41 \mathrm{~d}$ & $13.40 \mathrm{c}$ & $14.81 \mathrm{~b}$ & $15.95 \mathrm{a}$ & 0.90 & $14.53 \mathrm{a}$ & $12.44 \mathrm{~b}$ & 0.52 \\
\hline Fecundity & $8.80 \mathrm{~d}$ & $9.63 \mathrm{~d}$ & $10.98 \mathrm{c}$ & $13.08 \mathrm{~b}$ & $16.03 \mathrm{a}$ & $16.15 \mathrm{a}$ & 1.06 & $13.40 \mathrm{a}$ & $11.48 \mathrm{~b}$ & 0.61 \\
\hline Daily rate & $1.19 \mathrm{~b}$ & $1.30 \mathrm{ab}$ & $1.37 \mathrm{ab}$ & $1.36 \mathrm{ab}$ & $1.46 \mathrm{a}$ & $1.38 \mathrm{a}$ & 0.16 & $1.33 \mathrm{a}$ & $1.35 \mathrm{a}$ & 0.09 \\
\hline Life span & $26.62 \mathrm{bc}$ & $26.51 \mathrm{bc}$ & $26.04 \mathrm{c}$ & $26.64 \mathrm{bc}$ & $27.56 \mathrm{ab}$ & $28.68 \mathrm{a}$ & 1.12 & $32.42 \mathrm{a}$ & $21.59 \mathrm{~b}$ & 0.65 \\
\hline
\end{tabular}

The means are followed by different letters in the same rows are significantly divergent $(P<0.05$, Duncan $)$.

Table 7. Life table parameters of E. orientalis under different temperatures.

\begin{tabular}{|c|c|c|c|c|c|c|c|}
\hline Parameter & Temp. & $\begin{array}{l}\text { Date } \\
\text { palm }\end{array}$ & Mulberry & Plum & $\begin{array}{l}\text { Sweet } \\
\text { potato }\end{array}$ & $\begin{array}{c}\text { Indian } \\
\text { laburnum }\end{array}$ & $\begin{array}{c}\text { Castor } \\
\text { bean }\end{array}$ \\
\hline \multirow{2}{*}{ Mean generation time $\left(\mathrm{T}_{\mathrm{c}}\right)^{\mathrm{a}}$} & $25^{\circ} \mathrm{C}$ & 23.12 & 22.9 & 22.84 & 22.23 & 22.44 & 21.74 \\
\hline & $30^{\circ} \mathrm{C}$ & 12.99 & 22.84 & 12.99 & 13.39 & 13.31 & 14.28 \\
\hline \multirow{2}{*}{ Doubling time $(\mathrm{DT})^{\mathrm{a}}$} & $25^{\circ} \mathrm{C}$ & 12.38 & 10.3 & 9.0 & 7.3 & 4.85 & 6.03 \\
\hline & $30^{\circ} \mathrm{C}$ & 6.19 & 9.0 & 6.19 & 5.13 & 4.81 & 5.02 \\
\hline \multirow{2}{*}{ Net reproductive rate $\left(R_{0}\right)^{b}$} & $25^{\circ} \mathrm{C}$ & 3.68 & 4.72 & 5.92 & 8.34 & 25.06 & 12.25 \\
\hline & $30^{\circ} \mathrm{C}$ & 4.29 & 5.92 & 4.29 & 6.17 & 6.80 & 7.18 \\
\hline \multirow{2}{*}{ Intrinsic rate of increase $\left(r_{m}\right)$} & $25^{\circ} \mathrm{C}$ & 0.056 & 0.067 & 0.077 & 0.095 & 0.143 & 0.115 \\
\hline & $30^{\circ} \mathrm{C}$ & 0.112 & 0.077 & 0.112 & 0.135 & 0.114 & 0.138 \\
\hline \multirow{2}{*}{ Finite rate of increase $(\lambda)^{c}$} & $25^{\circ} \mathrm{C}$ & 1.05 & 1.07 & 1.08 & 1.10 & 1.15 & 1.12 \\
\hline & $30^{\circ} \mathrm{C}$ & 1.11 & 1.08 & 1.11 & 1.14 & 1.15 & 1.14 \\
\hline \multirow{2}{*}{$\begin{array}{l}\text { Gross reproduction rate } \\
(\text { GRR })^{\text {b }}\end{array}$} & $25^{\circ} \mathrm{C}$ & 6.42 & 7.06 & 8.65 & 11.4 & 33.7 & 15.4 \\
\hline & $30^{\circ} \mathrm{C}$ & 8.6 & 7.85 & 8.6 & 11.2 & 12.2 & 12.5 \\
\hline \multirow{2}{*}{$50 \%$ mortality $^{a}$} & $25^{\circ} \mathrm{C}$ & 27 & 29 & 28.7 & 28 & 29 & 29 \\
\hline & $30^{\circ} \mathrm{C}$ & 17 & 16 & 17 & 17 & 18 & 22 \\
\hline \multirow{2}{*}{ Survival rate $\%$} & $25^{\circ} \mathrm{C}$ & 0.7 & 0.75 & 0.77 & 0.80 & 0.85 & 0.9 \\
\hline & $30^{\circ} \mathrm{C}$ & 0.65 & 0.77 & 0.65 & 0.75 & 0.75 & 0.72 \\
\hline \multirow{2}{*}{ Sex ratio ( $q /$ total $)$} & $25^{\circ} \mathrm{C}$ & 0.65 & 0.66 & 0.70 & 0.75 & 0.76 & 0.75 \\
\hline & $30^{\circ} \mathrm{C}$ & 0.7 & 0.7 & 0.7 & 0.68 & 0.72 & 0.7 \\
\hline
\end{tabular}

\footnotetext{
${ }^{\mathrm{a}}$ Days ${ }^{\mathrm{b}}$ per generation ${ }^{\mathrm{c}}$ Individuals/female/ day
} 

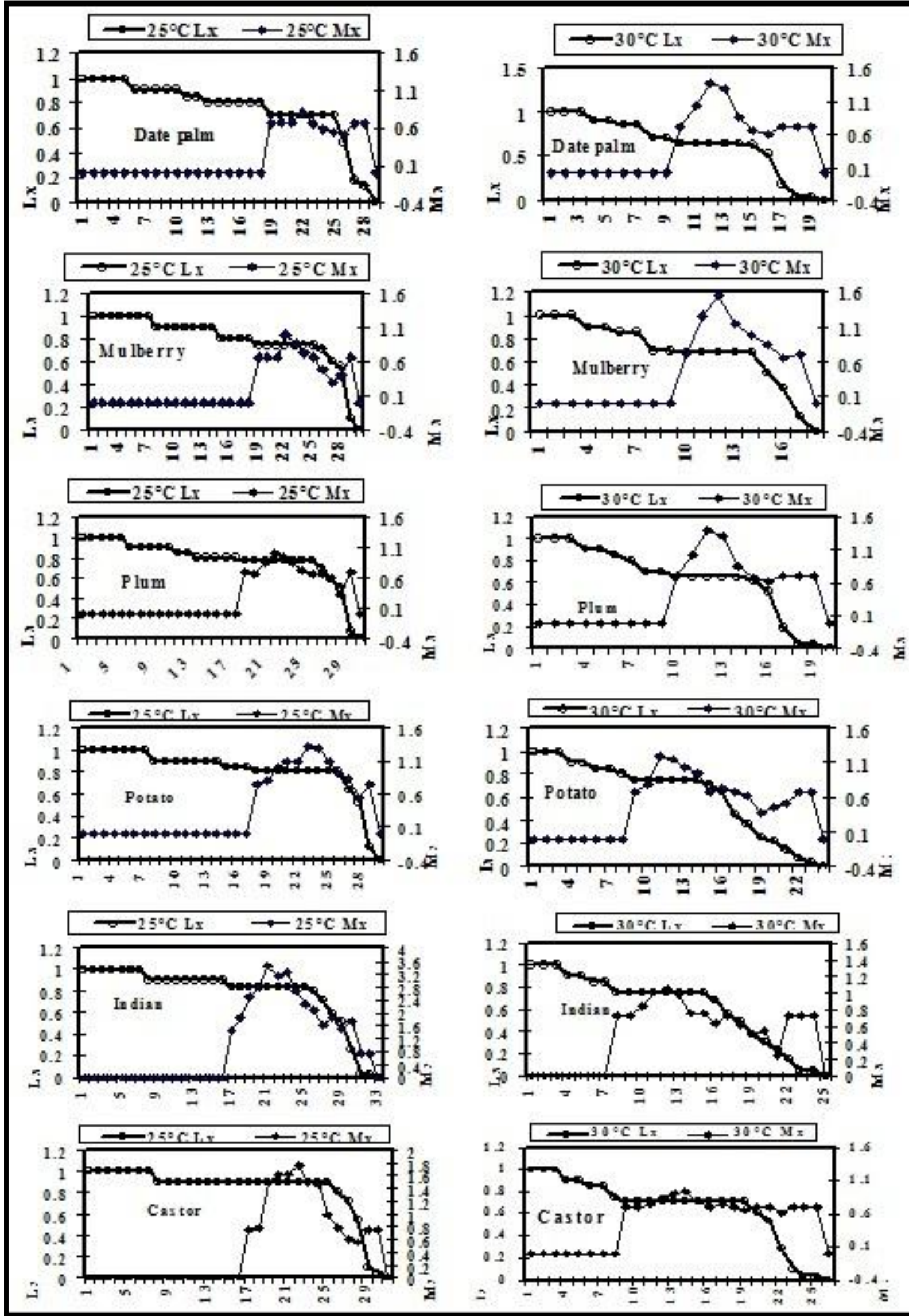

Fig. 1. Age specific survivorship (Lx) and age specific fecundity (Mx) for E. orientalis on six host plants and two different temperatures. 
Badii et al. 2003 studied the effect of five different constant temperatures on the life history and life table parameters of E. banksi on Sweet orange leaves. The intrinsic rates of natural increase were -0.0649 , $0.1723,0.1759,0.1973$ and -0.0711 ; net reproductive rates, $0.30,8.25,7.24,9.21$ and 0.44 ; mean generation times, $19.21,12.79,11.74,11.52$ and 11.64 days at 20 , $25,30,32.5$ and $35^{\circ} \mathrm{C}$, respectively. Imani et al. 2009 found that the mean generation time ( $\mathrm{T}$ ) is 22.83 days, the net reproductive rate $\left(\mathrm{R}_{0}\right)$ is 154.08 and the intrinsic rate of increase $\left(r_{m}\right)$ is 0.221 . The intrinsic rate of increase $\left(\mathrm{r}_{\mathrm{m}}\right)$ ranges from 0.144 at $30^{\circ} \mathrm{C}$ to 0.094 individuals per female daily at $20^{\circ} \mathrm{C}$. The population doubles in 4.79 days at $30^{\circ} \mathrm{C}$ and in 7.33 days at $20^{\circ} \mathrm{C}$ (Imani and Shishehbor, 2009). Sangeetha et al. 2013 reared E. orientalis on neem leaf discs at $35^{\circ} \mathrm{C}$, development times from egg to adult stage were 9.48days, oviposition period averaged 7.7 days and Fecundity averaged 30.1 eggs/ female. However, Elhalawany and Abdel-Wahed, 2013 reported that $T$. urticae maximum value of intrinsic rate of increase $\left(\mathrm{r}_{\mathrm{m}}\right) \quad 0.243$ and 0.297 individuals/ $9 /$ day, and maximum net reproductive rate (Ro) 47.51 and 63.47 individuals/ $q$ on Kostata and Hachiya varieties at $30{ }^{\circ} \mathrm{C}$, respectively. Maximum fecundity was obtained on Kostata variety at $30^{\circ} \mathrm{C}$ at day 15 was 8.93 eggs/ $/$ day. Finally, Dingxu et al. 2006 studied the influence of host species of deciduous fruit trees, like apple, peach, plum, cherry and apricot, on the development and reproduction of the hawthorn spider mite Tetranychus viennensis Zacher in the laboratory. They indicated that plum might be the best suitable plant for the spider mite among the plants tested due to shorter developmental period and higher intrinsic rate of increase, whereas cherry and apricot were least suitable due to their long developmental duration and low intrinsic rates of increase.

\section{Conclusion}

As a results of the above findings, it can be concluded that $30^{\circ} \mathrm{C}$ is favorable than $25^{\circ} \mathrm{C}$ for population build-up of $E$. orientalis on Indian laburnum and castor bean are affected the developmental time, especially egg duration and fecundity of that mite. Observations made under laboratory conditions can be valuable in understanding population dynamics and integrated pest management.

\section{References}

Abdelgayed, A.S., Negm, M.W., Eraky; S.A., Helal, T.Y., Moussa, S.F.M. 2017. Phytophagous and predatory mites inhabiting citrus trees in Assiut Governorate, Upper Egypt. Assiut J. Agric. Sci., 48(1):173-181.

Abdel-Wahed, N., Elhalawany, A.S. 2012. Effect of temperature degree on the biology and life table parameters of Tetranychus urticae Koch on two pear varieties. Egypt. Acad. J. Biolog. Sci., 4(1): 103-109.

Abou-Setta, M.A., Sorrell, R.W., Childers, C.C. 1986. Life 48: a BASIC computer program to calculate life table parameters for an insect or mite species. Fla. Entomol., 69(4): 690-697.

Al-Gboori, J.I. 1991. Biology of oriental citrus mite, Eutetranychus orientalis (Klein) on different citrus species.In Modern acarology, Dusbabec f. and Bukva J. Academia, Prague, 2, 607-611.

Assari, M. J. 2001. Biology of the citrus brown mite, Eutetranychus orientalis (Klein) on four citrus varieties and its seasonal population fluctuations in Bam. M Sc. Thesis. Tarbiat Modares University, Tehran, Iran.

Atwa, W.A., Abdel All, H.E., Afify, E.A. 1987. Response of Eutetranychus anneckei Meyer to temperature (Acari: Tetranychidae). Ann. of Agric. Sci., Ain Shams Univ., 32: 785-797.

Badii, J., Varela, M. H., Flores, S., Landeros, A. E. 2003. Temperature based life history and life table parameters of Texas citrus mite on orange (Acari: Tetranychidae). Syst. Appl. Acarol., 8: 25-38.

Birch, L.C. 1948. The intrinsic rate of natural increase of an insect population . J. Anim. Ecol., 17: $15-26$.

Childers, C.C. Abou-Setta, M. M., Nawar, M. S. 1991. Biology of Eutetranychus banksi: life tables on marsh grapefruit leaves at different temperatures (Acari: Tetranychidae). Inter. J. of Acarology. 17 (1): 29-35.

Dingxu, L., Yueli, H., Zuorui, S. 2006. Influence of host plant species on the development and reproduction of hawthorn spider mites. Front. For. China, 2: 182-189.

Elhalawany, A.S. 2001. Studies on some mite species infesting some fruit trees. M.Sc. Thesis Fac. Agric., Moshtohor Benha Unvi, 164pp.

Elhalawany, A.S. 2013. Biology and life table parameters of the date palm dust mite, Oligonychus afrasiaticus (McGregor) (Acari: Tetranychidae) as affected by host and controlled conditions. Acarines, 7 (1):19—24.

Elhalawany, A.S., Abdel-Wahed, N.M. 2013. Effect of temperature and host plant on developmental times and life table parameters of Tetranychus urticae Koch on Persimmon trees. (Acari: Tetranychidae). Egyptian J. Agric. Res., 91(2) 595-607.

El-Halawany, M.E., Abdel-Samad, M.A., ElNaggar, M.E. 2001. Mites inhabiting date palms. In Second Inter. Conf. on Date Palms (Al-Ain, UAE, March 25-27, 2001) pp.366-373.

Imani, Z., Shishehbor, P. 2009. Effect of temperature on life history and life tables of Eutetranychus orientalis (Klein) (Acari: Tetranychidae). Syst. Appl. Acarol., 14(1): 11-18.

Imani, Z., Shishehbor, P., Sohrabi, F. 2009. The effect of Tetranychus turkestani and 
Eutetranychus orientalis (Acari: Tetranychidae) on the development and reproduction of Stethorus gilvifrons (Coleoptera: Coccinellidae). J. of AsiaPacific Ent., 12: 213-216.

Jeppson, L.R., Keifer, H.H., Baker, E. W. 1975. Mites injurious to economic plants. University of California Press. Berkely. 614pp.

Klein, H.Z. 1936. Contributions to the knowledge of the red spider mites in Palestine. Bull Agric. Res. Stn. Rehovoth, 21: 163.

Krantz, G.W., Water, D.E. 2009. A Manual of Acarology. Oregon State University Book Stores, 807 pp.

Rasmy, A.H. 1977. Biology of the citrus brown mite, Eutetranychus orientalis as affected by some citrus species. Acarologia 19(2): 222-224.

Sangeetha G. Kaimal, Athira, A., Aswathi, S.B., Fathima Safna, Jishna, M.P., Akshaya, A. 2013. Breeding strategies of Eutetranychus orientalis (klein) (acari: tetranychidae) on neem. Int. J. of Scince and Nuture, 4(3): 468-472.

SAS Institute. 2003. SAS Statistics and Graphics Guide, Release 9.1. SAS Institute, Cary, North Carolina 27513, USA.

Siddig, M.A., Elbadry, E.A. 1971. Biology of the spider mite, Eutetranychus sudanicus. Ann. of the Entomol. Soc. of America, 64: 806-809.

Singh, J.; Singh, R.N., Rai, S.N. 2000. Expanding pest status of phytophagous mites and integrated pest management. IPM system in Agriculture (eds: R.K. Upadhayay, K.G. Mukherjee and O. P. Dubey), New Delhi, India. 7: 1-29.

Zaher, M.A. 1984. Survey and ecological studies on phytophagous, predaceous and soil mites in Egypt. I: Phytophagous mites in Egypt (Nile valley and Delta). PI 480 Programme. USA Project No. EG. ARS, 30. Grant. No, FG, Eg., 228 pp.

\section{Eutetranychus تأثير بعض العوائل النباتية و الحرارة على المظاهر البيولوجية لأكاروس الموالح البني orientalis (Klein) (Acari: Actinedida: Tetranychidae)}

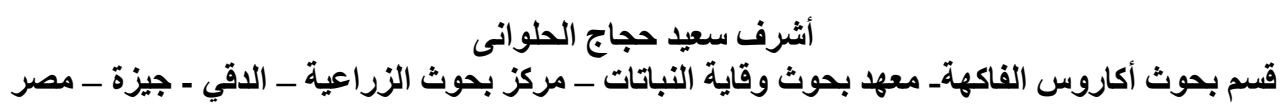

أكاروس الموالح البني Eutetranychus orientalis (Klein) هو أحد الآفات الرئيسية التي تصيب الموالح

و النخيل و الححاصيل الحقلية ونباتات الزينة. تم دراسة فترة التطور و التكاثر وجداول الحياة لأكاروس الموالح البني عند التغذية على ستة من العو ائل النباتية: الخروع، والنخيل، وخيار شنبر، و التوت، و البرقوق و البطاطا تحت الظروف المعطية

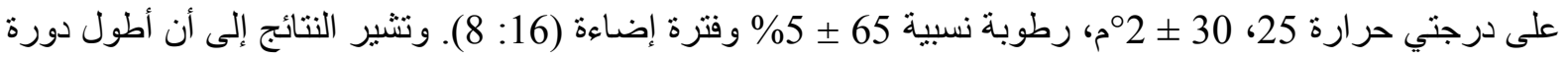

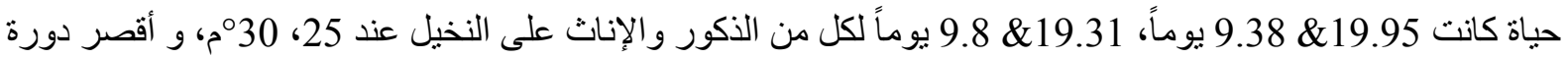

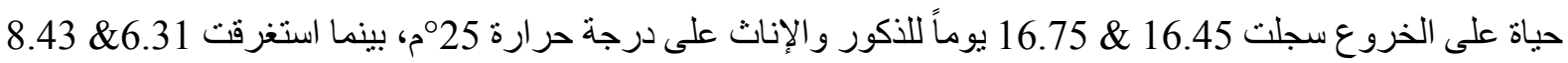
يوماً للذكور و الإناث عند 30 م على خيار شنبر على التوالي. تراوحت فترة حياة أنثى أكاروس الموالح البني من 13.53 إلى 15.13 يوماً عند 25×م، ومن 9.9 إلى 16.9 يوماً عند 30٪ م. وكان أعلى معدل للخصوبة الكلية 19.45 ، 19.4 ، 14.1 بيضة

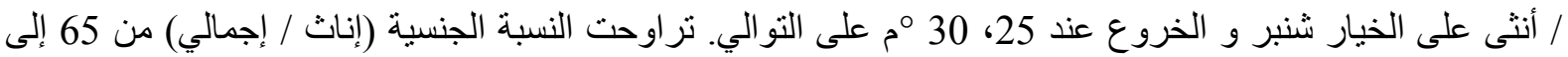

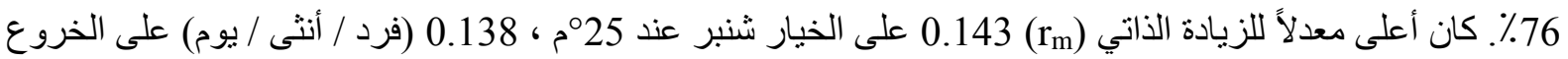
عند 30 م. كان لاى الأفر اد القدرة على التضاعف في أقصر وقت عند 30ْم (4.81 يومًا) على خيار شنبر و أطول وقت عند 25ْم (12.38 يومًا) على نخيل التمر. انخفض متوسط فترة الجيل (T) و الوقت اللازم لتضاعف الجيل (DT) مع زيادة درجة الحر ارة. هذا الأكاروس يفضل ارتفاع درجة الحرارة. وكانت نباتات الخروع و الخيار شنبر أكثر العو ائل تفضيلا عن غير ها من العو ائل تحت الدر اسة. 